\title{
Food Policies and Obesity in Low and Middle Income Countries
}

Kibrom A. Abay, Hosam Ibrahim, and Clemens Breisinger 


\section{TABLE OF CONTENTS}

Abstract ..iii

1 Introduction 1

2 Food Policies and Nutritional Implications .................................................................... 3

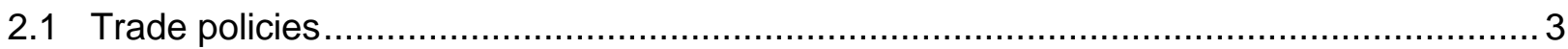

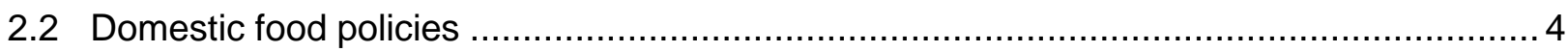

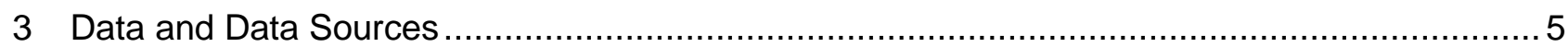

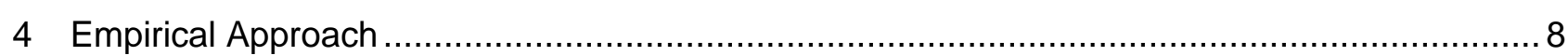

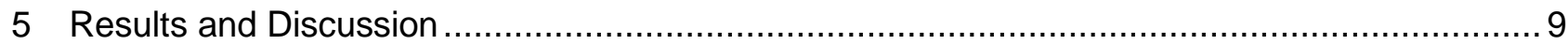

6 Heterogenous Responses and Robustness Exercises ................................................... 14

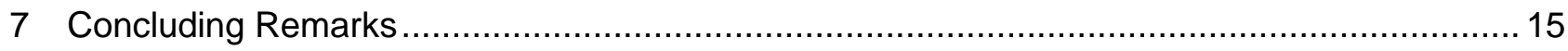

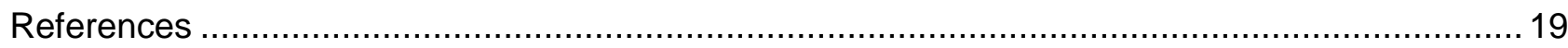

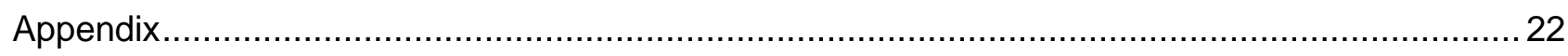

\section{LIST OF TABLES}

Table 1: Summary statistics for the analytical sample, by data source ..................................... 6

Table 2: Average tariff rates on sugar and confectionery food items and body weight outcomes .. 10

Table 3: Average tariff rates on fats and oils and body weight outcomes ................................. 11

Table 4: Average (aggregate) tariff rates on foods and body weight outcomes .......................... 12

Table 5: Heterogeneous implications of tariff rates on sugars and confectionery products on body

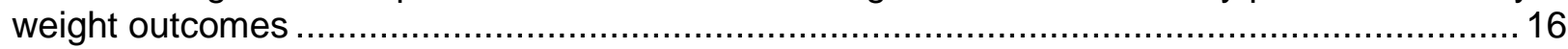

Table 6: Heterogeneous implications of tariff rates on fats and oils on body weight outcomes...... 16

Table 7: Heterogenous implications of tariff rates on all foods on body weight outcomes............. 17

Table A1: Body-mass Index and tariff rates for food imports for study countries, average............ 22

Table A2: Lagged tariff rates on sugars and confectionery products and body weight outcomes .. 23

Table A3: Lagged tariff rates on fats and oils and body weight outcomes ................................. 23

Table A4: Lagged (aggregate) tariff rates on food and body weight outcomes ........................... 24

\section{LIST OF FIGURES}

Figure 1: Average tariff rates for selected food items in low and middle income countries, 2005 to 2018

Figure 2: Average expenditure on subsidies as share of total government expenditures in low and middle income countries, 2000 to 2017 


\section{ABSTRACT}

Understanding the public health implication of fiscal policies is crucial to combat recently increasing overweight and obesity rates in many low-and-middle income countries (LMICs). This study examines the implication of food policies, mainly tariff rates on "unhealthy" foods, including sugar and confectionery products as well as fats and oils, and governments' subsidies on individuals' body weight outcomes. We compile several macro- and micro-level datasets that provide for several LMICs macro-level information on food policies and micro-level anthropometric data. We exploit temporal dynamics in tariff rates on "unhealthy" foods and governments' spending on subsidies to estimate fixed effects models characterizing the evolution of body weight outcomes. We find that temporal dynamics in tariff rates on unhealthy and energy-dense foods are significantly and negatively associated with body weight. Conditional on several observable and time-invariant unobservable factors, a decrease in tariff rates on sugar and confectionary foods or fats and oils is associated with an increase in overweight and obesity rates. On the other hand, an increase in subsidy rates, as a share of government expenditure, is significantly associated with higher overweight and obesity rates. Interestingly, we find that the implications of these food policies are more pronounced among poorer individuals. This is intuitive because relatively poorer households are more likely to spend a larger share of their income on food consumption or unhealthy foods, and these types of households are beneficiaries of government subsidies in many LMICs. These findings have important implications for informing public health policies in LMICs, which are experiencing an unprecedented rise in overweight and obesity rates.

Keywords: Food policies, fiscal policies, trade policies, subsidies, body mass index, nutrition transition, overweight, obesity.

JEL classification: Q18, Q17, F13, H24, I12. 


\section{INTRODUCTION}

Global overweight and obesity rates have almost tripled since 1975 and annually account for about 4 million deaths (Shekar and Popkin 2020). Predictions suggest that these rates are expected to further increase in the next few decades ( $\mathrm{Ng}$ et al. 2014; Kilpi et al. 2014; NCDRisC 2017). These increases in overweight and obesity rates are relatively higher in lowand-middle income countries (LMIC), while these trends have been slowing down in highincome countries ( $\mathrm{Ng}$ et al. 2014; Shekar and Popkin 2020). For instance, about 70 percent of the globally overweight or obese people - nearly 2 billion people - live in LMICs (Shekar and Popkin 2020). High overweight and obesity rates are strongly linked to a high prevalence of non-communicable diseases (NCDs), which are now among the leading causes of death in many regions of the world (Shekar and Popkin 2020). The prevalence of NCDs has increased sharply in many LMICs in the last few decades, while declining somewhat in high-income countries (Miranda et al. 2019). The overall annual cost of overweight and obesity in LMICs is projected to reach about USD 7 trillion in the next 15 years (Shekar and Popkin 2020).

Several explanations account for the increasing overweight and obesity rates in many LMICs, including the nutrition transition seen in many parts of the world, which led to a shift to more processed and energy-dense foods (Popkin 1999; Popkin 2003; Harpham et al. 2003; Monda et al. 2007). Furthermore, many LMICs are going through some form of demographic transition, including significant levels of urbanization. These processes involve a transition in lifestyle as people shift to more sedentary livelihoods with limited physical activity (Popkin, Adair, and Ng 2012; Popkin and Du 2003; Popkin 2003; Traill et al. 2014; Popkin 1999; Harpham et al. 2003; Monda et al. 2007; Abay and Amare 2018). Such nutrition and demographic transitions are commonly associated with unhealthy weight gains.

Despite a lack of rigorous empirical evidence, domestic food policies and trade policies may also contribute to nutritional transitions and associated body weight outcomes. International trade can instrumentally shape food systems and influence dietary patterns in ways that can increase overweight and obesity rates. Globalization and associated food trade can affect the demand and supply of food in local food markets (Costa-Font and Mas 2016). Various trade policies, including trade liberalization, in Central America and the Pacific region are shown to have increased food imports and food availability (Thow and Hawkes 2009; Thow et al. 2011). Trade policies, including tariff rates and taxes, can also influence food systems and, hence, serve as instruments to address public health concerns. For instance, governments can use tariff rates to discourage "unhealthy" foods or to promote heathy foods (Hawkes et al. 2012; WHO 2015; Thow et al. 2018; Donaldson 2015; Baker et al. 2018; Allcot et al. 2019; Alsukait et al. 2020).

Similarly, the domestic food policies of governments, including direct food subsidies and agricultural input subsidies, can influence local diets and consumption patterns. Many LMICs have food subsidy or agricultural input subsidy programs which may affect the production, processing, and retailing of specific foods. Most food subsidy programs in LMICs target basic food items, including wheat, rice, maize, sugar, and cooking oil, while agricultural input subsidy programs usually support the production of specific strategic crops, mainly cereals. Theoretically, these policies can reduce the relative price of such food items, encouraging people to overconsume subsidized energy-dense food items while discouraging consumption of relatively more expensive nutrient-rich healthy foods. However, empirical 
evidence on the implication of these fiscal policies and trade regimes on nutritional outcomes remains scarce. This paper aims to fill this gap by combining individual-level anthropometric data with macroeconomic indicators of fiscal policies.

This paper examines the implication of alternative trade and fiscal policies, mainly tariff rates on foods and government subsidies, on overweight and obesity rates in LMICs. Due to the strong linkage between consumption of energy-dense foods and body weight, we focus on tariff rates on unhealthy foods: sugars and confectionary items and fats and oils. Similarly, to capture the subsidy dimension of a government's domestic food policies, we employ the share of government expenditure on subsidies, including food and agricultural inputs subsidies as well as subsidies to other sectors.

In addition to quantifying the overall implication of these fiscal policies, we also examine potentially heterogenous responses across wealth quintiles. We hypothesize that poor and rich households may have varying degrees of exposure to these policies. For instance, poorer households are usually more price-sensitive to changes in food prices. Furthermore, healthy foods are relatively more expensive than unhealthy foods (Headey and Alderman 2019; Hirvonen et al. 2020), suggesting poorer households are more likely to consume cheaper and unhealthy foods. In many LMICs, food subsidies target poorer households, implying that any change in government spending on food and agricultural subsidies can disproportionally affect poorer households.

We merge macro-and micro-level data for several LMICs across several years. We employ two sources of macro data. We use the World Trade Organization (WTO) database to extract tariff rates for several food products and the World Development Indicators (WDI) database from the World Bank for extracting the share of governments' expenditure on subsidies. The micro-level data we employ come from the Demographic and Health Survey (DHS) program, which provides anthropometric information covering many LMICs. Compiling these various macro- and micro-level datasets helps to address this underresearched agenda - the implication and potential of fiscal policies to explain and address rising overweight and obesity rates. We exploit temporal dynamics in fiscal policies to estimate alternative fixed effects models to examine potential dynamics of tariff rates for unhealthy foods on body weight outcomes. We, thus, examine whether the general decline in tariff rates for unhealthy foods, commonly attributable to countries' accession to global and regional trade agreement, is associated with changes in overweight and obesity rates.

We find that temporal dynamics in such fiscally-oriented food policies are significantly associated with changes in body weight outcomes. A reduction in tariff rates on unhealthy foods is significantly associated with higher body weights and higher overweight and obesity rates. Countries experiencing a reduction in tariff rates on unhealthy foods are more likely to witness an increase in overweight and obesity rates. We also find that an increase in government expenditure on subsidies as a share of total government expenditure also is significantly associated with an increase in overweight and obesity rates. Interestingly, we find that the implications of these food policies are more pronounced among poorer individuals. This is intuitive because relatively poorer households are more likely to respond to changes in food prices than are richer households and poorer households are more likely than wealthier households to be beneficiaries of government subsidies in many LMICs.

Our findings have important implications for informing global and domestic public health policies to address the increasing obesity rates and their associated NCDs burden in many LMICs. The strong linkage between trade policies and body weight suggests that these 
policies can be powerful instruments to combat obesity and associated NCDs. Recognition of this association has lately been getting some traction among policy makers. For example, the World Health Organization (WHO) recently highlighted that fiscal policies, such as taxes and subsidies, can be effective instruments to prevent NCDs (WHO 2015). Our findings contribute to this evolving debate on the role that fiscal policies and similar macro-level instruments might play in combatting obesity and associated NCDs (WHO 2015; Thow et al. 2018). Similarly, policy makers and economists are arguing for inclusion of health costs into the cost-benefit analysis for new trade agreements (UNDP 2013). The heterogenous implication of fiscal policies that we document in this study sheds new light on how fiscal policies, such as increases in taxes and subsidies, may have differential impact on various groups within societies.

\section{FOOD POLICIES AND NUTRITIONAL IMPLICATIONS}

Fiscal policies, including trade and domestic government policies, have the potential to shape global food systems and influence the domestic food environment through their effects on food production, processing, and distribution.

\subsection{Trade policies}

The last few decades have seen major trade policy changes in many LMICs, including trade liberalization with accession to WTO and participation in other major trade agreements. Trade policies can affect domestic food environments and global food systems through several direct and indirect channels. First, trade policies, including easing trade barriers and reducing tariff rates, can increase food imports, which in turn can affect the domestic food environment by increasing the availability and affordability of various foods. Trade liberalization is shown to increase local food production and exports, while also being associated with increased consumption of unhealthy foods and sugary drinks (Friel et al. 2013; Snowdon and Thow 2013; Schram et al. 2015; Baker et al. 2016; Hawkes et al. 2012). ${ }^{1}$

Second, efforts to ease trade barriers may encourage flows of foreign direct investment (FDI), including investment in food processing industries and supermarket chains, which can increase domestic production of processed food. As trade and foreign investment barriers are reduced; emerging economies become more import-dependent and increasingly attractive to FDI in their food processing sector and in food marketing, particularly supermarkets (Hawkes 2005; Shankar 2017). Trade liberalization policies are commonly associated with flourishing of food processing industries (Hawkes 2006). Trade liberalization in many LMICs is also transforming local food retail sectors by introducing large supermarket chains, which may result in the substitution of components of traditional diets with cheaper imported foods (Blouin et al. 2009).

Third, trade policies can influence the relative prices of foods, which can affect consumers' food choices, dietary preferences, and consumption patterns (Shankar 2017). Trade openness encourages transnational food corporations to enter local food-processing chains, leading to increased supply and reduced retail prices of processed foods and soft drinks (Friel et al. 2013). Similarly, a reduction in tariff rates on unhealthy foods reduces the

\footnotetext{
${ }^{1}$ Other recent studies show that trade liberalization and associated trade openness increases dietary diversity (Krivonos and
} Kuhn 2019). 
relative prices of these foods relative to healthy foods traditionally consumed and encourages the consumption of the cheaper unhealthy foods. The implication and size of such substitution effects depend on the availability of other substitutes in local markets as well as the marginal differences in prices across these products.

Fourth, trade policies can directly or indirectly influence consumers' income and purchasing power as well as their distribution across households. For instance, a country's Increasing trade may trigger economic growth in a country that can increase individuals' demand for food (Shankar 2017). A reduction in tariff rates on specific foods imply improved purchasing power, an income effect that can affect consumption of both healthy and unhealthy foods.

The effect of fiscal policies, such as tariff rates and subsidies, are likely to vary across groups in societies. For instance, tariffs and taxes on unhealthy foods are more likely to have a greater effect on those who consume these foods - more likely poorer households, since healthier foods are more expensive (Headey and Alderman 2019). Furthermore, poorer households devote a larger share of their income on food than richer households. Thus, an increase in tariff rates on unhealthy foods may have differential impact between poor and rich households. Changes in tariff rates for such foods are more likely to affect nutritional outcomes in poorer households than in richer households.

\subsection{Domestic food policies}

Governments' agricultural input and food subsidies can also influence domestic food systems. Many LMICs provide agricultural input subsidies and market-related support for farmers. Such policies involve provisions of modern inputs, such as fertilizers, irrigation technologies, and extension services, as well as price guarantees. Most input subsidy programs target specific staple food items and are largely driven by farmer support programs (Barrett 2002). These agricultural policies can affect food environments in two important ways. First, agricultural input subsidies in LMICs encourage the production of a few staple cereals, which can increase the productivity of these specific crops and their availability in local food markets. These subsidies could induce overproduction of specific types of cereals with potential implications on the composition of domestic diets. Second, apart from increasing the production and availability of subsidized food items, agricultural input subsidies and market-related support can make specific foods cheaper for consumers and food-processing industries, further affecting consumers' preferences as well as the quality of foods in the market (Hawkes et al. 2012). Research on the political economy of agricultural input subsidies and food assistance programs shows that such programs generally are ineffective due to inefficiencies and targeting problems (Barrett 2002).

Direct food subsidies are also common policy instruments in many LMICs. Such consumer subsidy programs target staple food items, including wheat, sugar, and cooking oil. These programs are meant to ensure food security and stabilize the price of frequently purchased food items. In some LMICs, food subsidy programs cost governments a substantial share of their budgets. For instance, the cost of Egypt's food subsidy program amounts to about 2 percent of national GDP and between 5 and 6 percent of annual government expenditure (Abdalla and Al-Shawarby 2018). Food subsidy programs affect consumers' diets through income and substitution effects (Timmer et al. 1983). First, subsidizing certain food items increases consumers' real income and purchasing power, which can increase demand for both subsidized and nonsubsidized food. Second, subsidized food items increase the relative price of nonsubsidized foods, encouraging the 
substitution of the latter with the former. If food subsidy programs are not nutrition-sensitive, this substitution may have important adverse implications on the composition of diets and the health outcomes of individuals. The overall effect of food subsidies in addressing their objectives remains questionable (Asfaw 2007; Jensen and Miller 2011; Ecker et al. 2016). Furthermore, most of these programs are criticized for their inefficiencies and targeting problems (Löfgren and El-Said 2001; Kochar 2005; Alderman, Gentilini, and Yemtsov 2018).

Despite these theoretically intuitive linkages between alternative food policies and nutritional outcomes, direct evidence on the implication of trade policies and overweight and obesity rates remains scarce. Furthermore, some of these trade policies have multidimensional objectives and effects, which may ambiguously affect nutritional outcomes (Hawkes, Chopra, and Friel 2009; Krivonos and Kuhn 2019). Empirical identification of the overall effect of trade and food policies can inform and help governments design adequate nutrition-sensitive fiscal policies. Uncovering potential heterogenous impacts of such fiscal policies can also inform the targeting and effectiveness of these policies.

\section{DATA AND DATA SOURCES}

Datasets providing detailed information on both trade policies, particularly trade in food, and health outcomes of individuals are scant. To address this limitation, we combine macro-level and micro-level data sources. We employ two sources of macro data: the WTO database for tariff rates for several products and countries, and the WDI database from the World Bank for the share of governments' expenditure on subsidies. The WTO database provides information on applied tariff rates by commodity for the period between 2005 and 2017. The WDI database also provides information on macroeconomic indicators, including GDP per capita. The tariff rates we employ in this study represent simple-average applied ad valorem (or ad valorem equivalents of non-ad valorem) duty rates to "most favored nations" for about 22 product groups. As unhealthy foods are strongly linked with obesity rates, we are interested in examining the implication of tariff rates on the domestic consumption of unhealthy foods. We thus employ tariff rates on sugars and confectionary products and on fats and oils. We also generate an aggregate food tariff rate variable that is a simple average of tariffs applied across several food categories: animal foods, cereals, dairy products, fish, fruits and vegetables, fats and oils, and sugars and confectionary products.

The micro-level data we employ come from the Demographic and Health Survey (DHS) program, which provides anthropometric information covering many LMICs. The DHS data are collected using relatively comparable methods across countries and time, providing detailed anthropometric information for children and adults. However, the DHS program mainly focuses on women and children, for which reason we focus our analysis on women.

Merging these three sources of data allows us to examine the implication and potential of fiscal policies to address rising overweight and obesity rates in LMICs. However, neither the WTO database nor the DHS program covers all LMICs in the world. Out of the LMICs countries covered by the DHS program, 31 countries have complete information on tariff rates for several food products and on government share of expenditure on subsidies This gives us a sample from the DHS of about 600,000 women surveyed in the years 2005 to 2016. ${ }^{2}$

\footnotetext{
${ }^{2}$ We exclude pregnant women to preclude the effect of pregnancy on body weight.
} 
Table 1 provides summary statistics and the sources of data used in our analysis. These data are pooled across countries and years. We follow WHO guidelines to classify and define overweight and obesity levels - a woman is classified as obese if her BMI is $30 \mathrm{~kg} / \mathrm{m}^{2}$ or above, while women with a BMI of $25 \mathrm{~kg} / \mathrm{m}^{2}$ or more, which includes individuals with BMI greater than $30 \mathrm{~kg} / \mathrm{m}^{2}$, are overweight. Appendix Table A1 provides a list of the countries examined with their average BMI for women and their tariff rates for unhealthy foods.

Table 1: Summary statistics for the analytical sample, by data source

\begin{tabular}{|c|c|c|}
\hline & Mean & $\begin{array}{l}\text { Standard } \\
\text { deviation }\end{array}$ \\
\hline \multicolumn{3}{|l|}{ Demographic and Health Surveys } \\
\hline BMI, kg/m2 & 24.39 & 5.21 \\
\hline Overweight, 0/1 & 0.37 & 0.48 \\
\hline Obese, $0 / 1$ & 0.14 & 0.34 \\
\hline Education: Illiterate, 0/1 & 0.22 & 0.42 \\
\hline Primary education, 0/1 & 0.26 & 0.44 \\
\hline Secondary education, 0/1 & 0.23 & 0.42 \\
\hline Tertiary education, 0/1 & 0.28 & 0.45 \\
\hline Woman has a child, 0/1 & 0.74 & 0.44 \\
\hline Wealth: Poorest wealth quintile & 0.19 & 0.39 \\
\hline Poorer wealth quintile & 0.20 & 0.40 \\
\hline Middle wealth quintile & 0.20 & 0.40 \\
\hline Richer wealth quintile & 0.20 & 0.40 \\
\hline Richest wealth quintile & 0.20 & 0.40 \\
\hline Rural household, 0/1 & 0.54 & 0.50 \\
\hline \multicolumn{3}{|l|}{ World Trade Organization } \\
\hline Tariff rate on sugar and confectionary foods, average, $\%$ & 13.2 & 6.71 \\
\hline Tariff rate on fats and oils, average, $\%$ & 9.8 & 4.66 \\
\hline Tariff rate on food items, average, $\%$ & 14.8 & 5.91 \\
\hline \multicolumn{3}{|l|}{ World Development Indicators } \\
\hline Expenditure on subsidies, as share of total government expenditure, $\%$ & 32.1 & 13.01 \\
\hline GDP per capita, constant 2010 US\$ & 2,690 & $1,983.0$ \\
\hline Number of countries & \multicolumn{2}{|c|}{31} \\
\hline Number of women & \multicolumn{2}{|c|}{598,209} \\
\hline Time period & \multicolumn{2}{|c|}{2005 to 2016 (12 years) } \\
\hline
\end{tabular}

Source: Compiled by authors.

In terms of trade policies, tariff rates on sugars and confectionery products across countries and years amount to over 13 percent on average, while the corresponding rate for fats and oils averages 10 percent. The overall average tariff rate on all food items is 15 percent. Figure 1 shows the evolution of tariff rates across time. Tariff rates have been generally declining for all products, partly due to trade liberalization measures and countries accession to international trade agreements, including accession to WTO (e.g., Krivonos and Kuhn 2019). Most LMICs have recently joined international trade agreements, inducing reduction in average tariff rates for all foods, including tariff rates on unhealthy foods. 
Figure 1: Average tariff rates for selected food items in low and middle income countries, 2005 to 2018

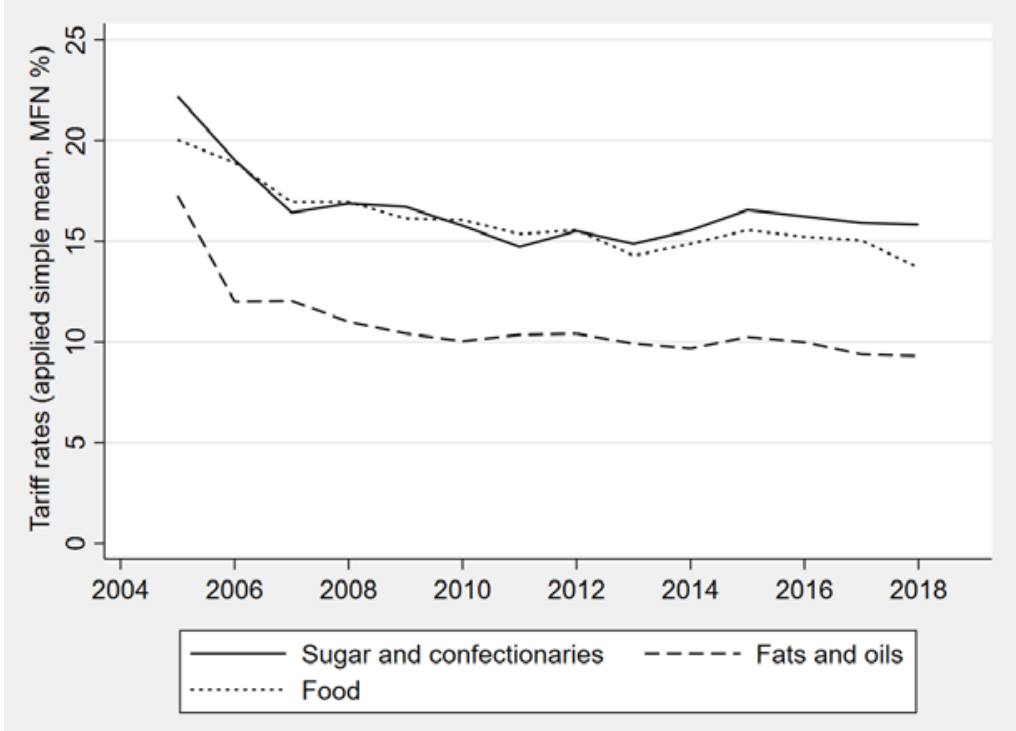

Source: World Trade Organization (WTO) and authors' own calculation

We extract data on governments' spending on subsidies as a share of overall government expenditure as well as other macro-level indicators, including per capita GDP (in constant 2010 USD), from the WDI database. One limitation of our information on governments' spending on subsidies is that it not only covers food subsidies, but, rather, subsidies in all sectors of the economy. The subsidy expenditure variable from the WDI includes government spending on:

- $\quad$ subsidies on specific foods (staple food items) and nonfood commodities (e.g., fuel);

- subsidies on agricultural inputs (e.g., fertilizer subsidies);

- subsidies and grants for social services and social benefits; and

- subsidies and grants for developing marginalized regions (World Bank 2019).

Given this data limitation, the fact that we lack specific information on food subsidies can affect our understanding of the relationship between food subsidies and body weight outcomes. However, agricultural input and food subsidies remain major components of the overall subsidy spending in many countries.

Figure 2 shows the evolution of government subsidies as share of government expenditure for low-income (LIC) and middle income (MIC) countries separately. On average, government's expenditure on subsidies have been increasing in the last two decades, despite significant variation in these trends across countries. 
Figure 2: Average expenditure on subsidies as share of total government expenditures in low and middle income countries, 2000 to 2017

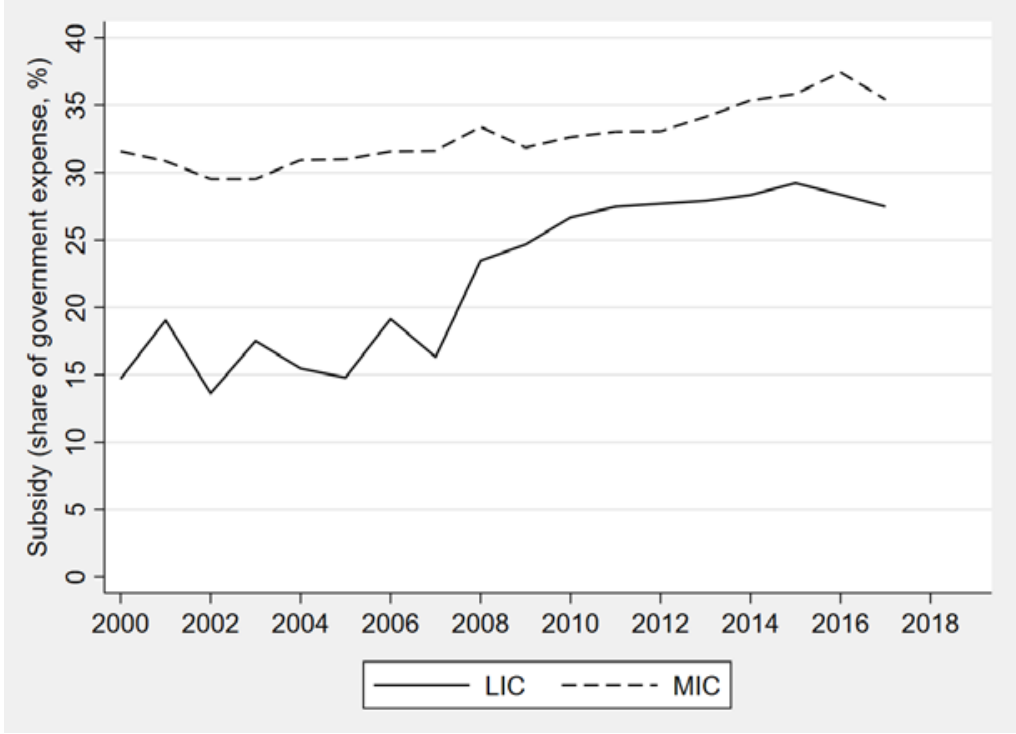

Source: World Development Indicators (WDI) and authors' own calculation Note: LIC = Lower income countries; MIC = Middle income countries

\section{EMPIRICAL APPROACH}

Estimating the relationship linkage between trade (food) policies or subsidy programs and body weight outcomes can be confounded by several observable and unobservable factors. For instance, countries with varying income levels and economic growth rates may have systematically different trade policies or subsidy programs and nutritional outcomes.

Similarly, countries have varying cultural contexts, farming systems, levels of urbanization, natural resources, and dietary patterns, all of which may affect the relationship between the policies or subsidies and body weight outcomes. Finally, such policies or subsidies may also endogenously respond to body weight outcomes, particularly if trade policies, e.g., tariff rates are introduced as policy responses to public health concerns.

We, thus, need an approach that accounts for potential temporal and spatial variations across countries. We apply an empirical approach that can capture both observable individual characteristics and unobservable time-invariant differences across countries. The following fixed effects model controls for time (years) and country fixed effects, along with several other time-varying individual and country-specific characteristics. This approach allows us to exploit the implication of potential dynamics in trade (food) policies on temporal variations in nutritional (body weight) outcomes. More specifically, we estimate the following equation:

$$
Y_{i c t}=\alpha_{c}+\beta_{1} T F_{c t}+\beta_{2} X_{i c t}+\beta_{2} Z_{c t}+\alpha_{t}+\varepsilon_{i c t}
$$

Where $Y_{i c t}$ stands for body weight measures for a woman $i$ in country $c$ and survey year t. $\alpha_{c}$ represents a vector of country fixed effects, which can control for any unobservable time-invariant differences across countries, including cultural, geographic, and climaterelated factors that remain broadly constant over time. $T F_{c t}$ stands for measures and indicators of trade and food policies or subsidies for each country and time period. We also keep higher-order effects of trade and food policies whenever they appear statistically relevant. $X_{\text {ict }}$ captures additional observable demographic and socioeconomic 
characteristics of women, including education and wealth status. ${ }^{3} Z_{c t}$ captures additional time-varying characteristics of countries, including GDP per capita. $\alpha_{t}$ captures time trends, controlling for aggregate trends in the evolution of food systems or aggregate nutritional transitions or related macroeconomic trends.

The empirical model specified in equation (1) exploits temporal variations in trade (food) policies or subsidies to uncover their nutritional and public health implications. These fixed effects specifications are immune to time-invariant cross-country differences. However, there might still be some endogeneity problems arising from reverse causality, if trade policies or subsidies respond to public health concerns. Furthermore, some trade policies may need some time to influence domestic food systems and food environments. Overweight and obesity rates are also cumulative outcomes of underlying drivers and causes. Thus, in our robustness exercise we lag the key trade policy indicators and estimate a slightly different variant of equation (1).

We estimate the empirical specification in equation (1) for each type of trade (food) policy or subsidy indicator. As discussed in Section 2, we particularly examine the implication of the following: (i) tariff rates on sugars and confectionary products, (ii) tariff rates on fats and oils, (iii) tariff rates on foods, and (iv) government spending on subsidies as a share of government expenditure. We rely on individual-level data from the DHS program, which covers hundreds of women in each sampling unit (cluster) in each round. We thus cluster standard errors at each sampling unit (cluster) in each round of the DHS in a country. ${ }^{4}$

\section{RESULTS AND DISCUSSION}

In this section we report and discuss the main results associated with equation (1). Tariff rates on different unhealthy foods are strongly correlated among each other, thus, we separately estimate equation (1) for each item. However, we incorporate the spending by governments on subsidies in all of the estimations. Table 2 provides estimation results on the relationship between tariff rates on sugars and confectionary products. Columns (1) to (3) characterizes women's BMI, while columns (4) to (6) and (7) to (9) model overweight and obesity rates, respectively. For each body weight outcome, the first column models the outcome as a function of countries' trade and food policies, namely tariff rates on unhealthy foods and share of government spending on subsidies, along with year and country fixed effects. The next column extends this specification and adds demographic and socioeconomic characteristics of the women in our DHS datasets, while the last column controls for per capita real GDP, a time-varying macroeconomic characteristic.

\footnotetext{
${ }^{3}$ We also include indicators for women's age and for whether a woman has had a child. Whether a woman has had a child was found to matter most for women's body weight. We opted to use this indicator instead of using age of women, which also suffers from missing values in our data.

${ }^{4}$ In our robustness exercises we cluster standard errors at country level for each DHS round. The standard errors remain comparable.
} 
Table 2: Average tariff rates on sugar and confectionery food items and body weight outcomes

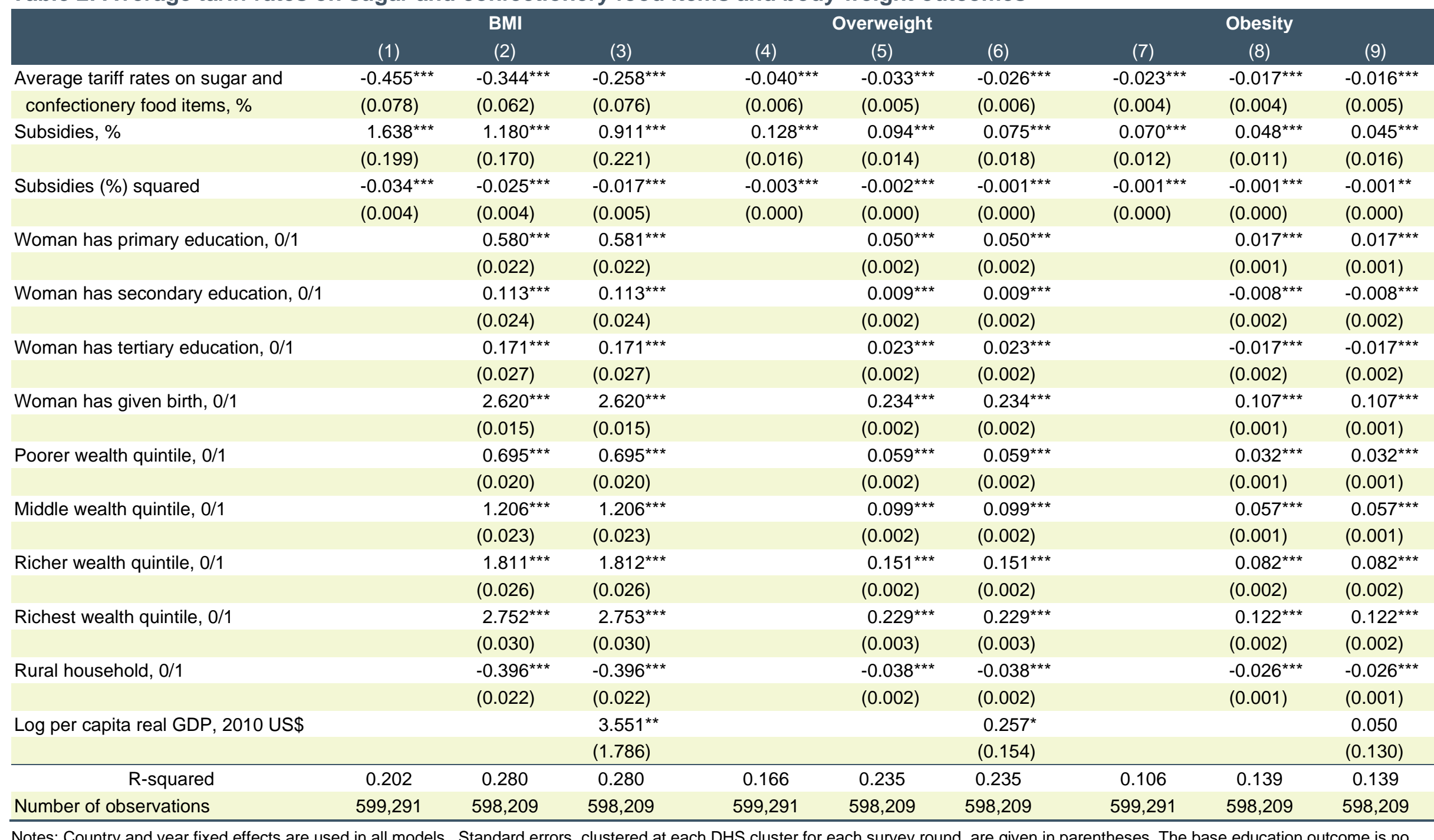

Notes: Country and year fixed effects are used in all models. Standard errors, clustered at each DHS cluster for each survey round, are given
education, while the base wealth quintile is the poorest wealth quintile. BMI = Body mass index $\left(\mathrm{kg} / \mathrm{m}^{2}\right) .{ }^{*} p<0.10,{ }^{* *} p<0.05,{ }^{* \star *} p<0.01$. 
Table 3: Average tariff rates on fats and oils and body weight outcomes

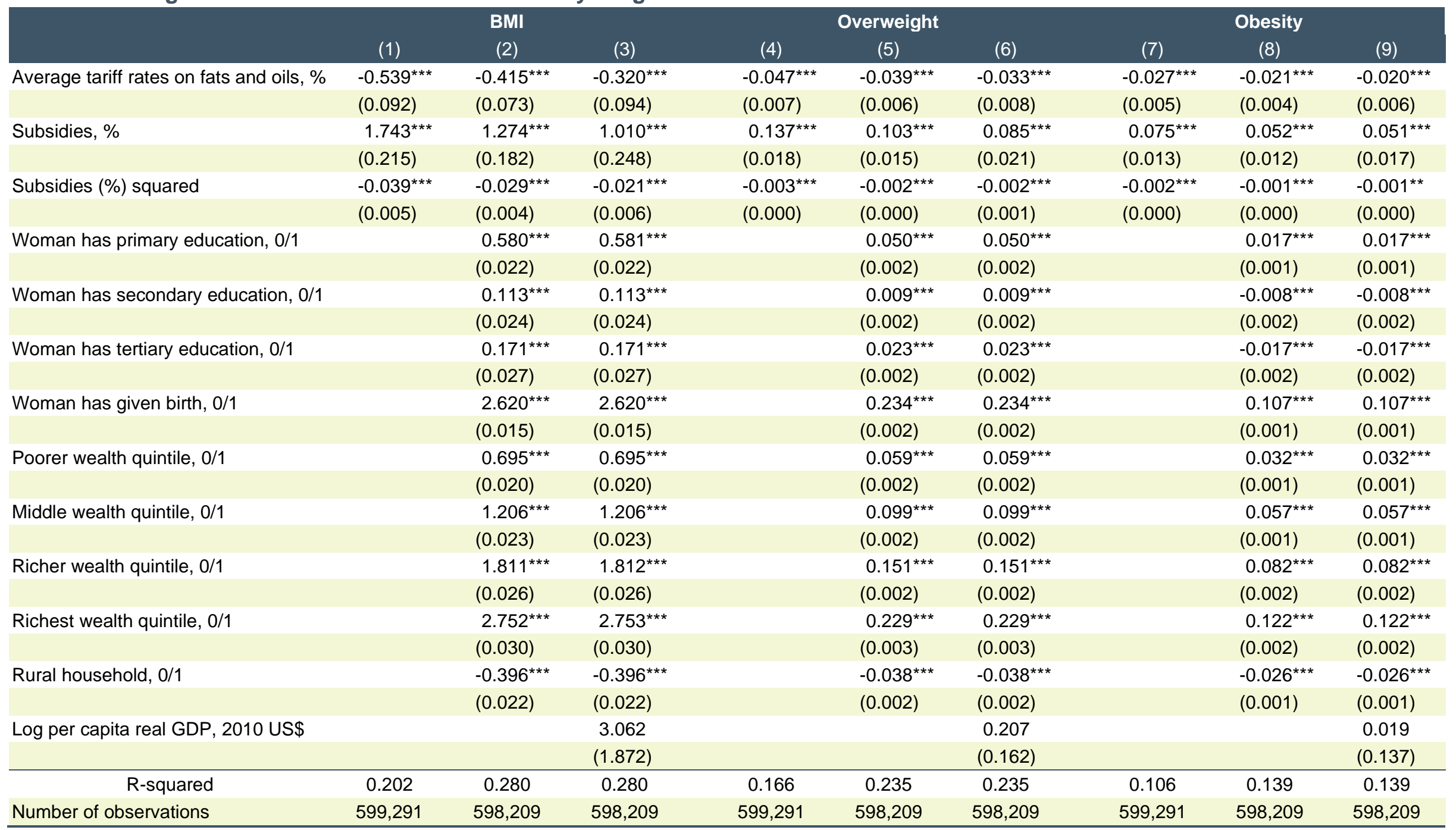

Notes: Country and year fixed effects are used in all models. Standard errors, clustered at each DHS cluster for each survey round, are given in parentheses. The base education outcome is no education, while the base wealth quintile is the poorest wealth quintile. BMI = Body mass index $\left(\mathrm{kg} / \mathrm{m}^{2}\right) .{ }^{*} \mathrm{p}<0.10,{ }^{* \star} \mathrm{p}<0.05,{ }^{\star \star \star} \mathrm{p}<0.01$. 
Table 4: Average (aggregate) tariff rates on foods and body weight outcomes

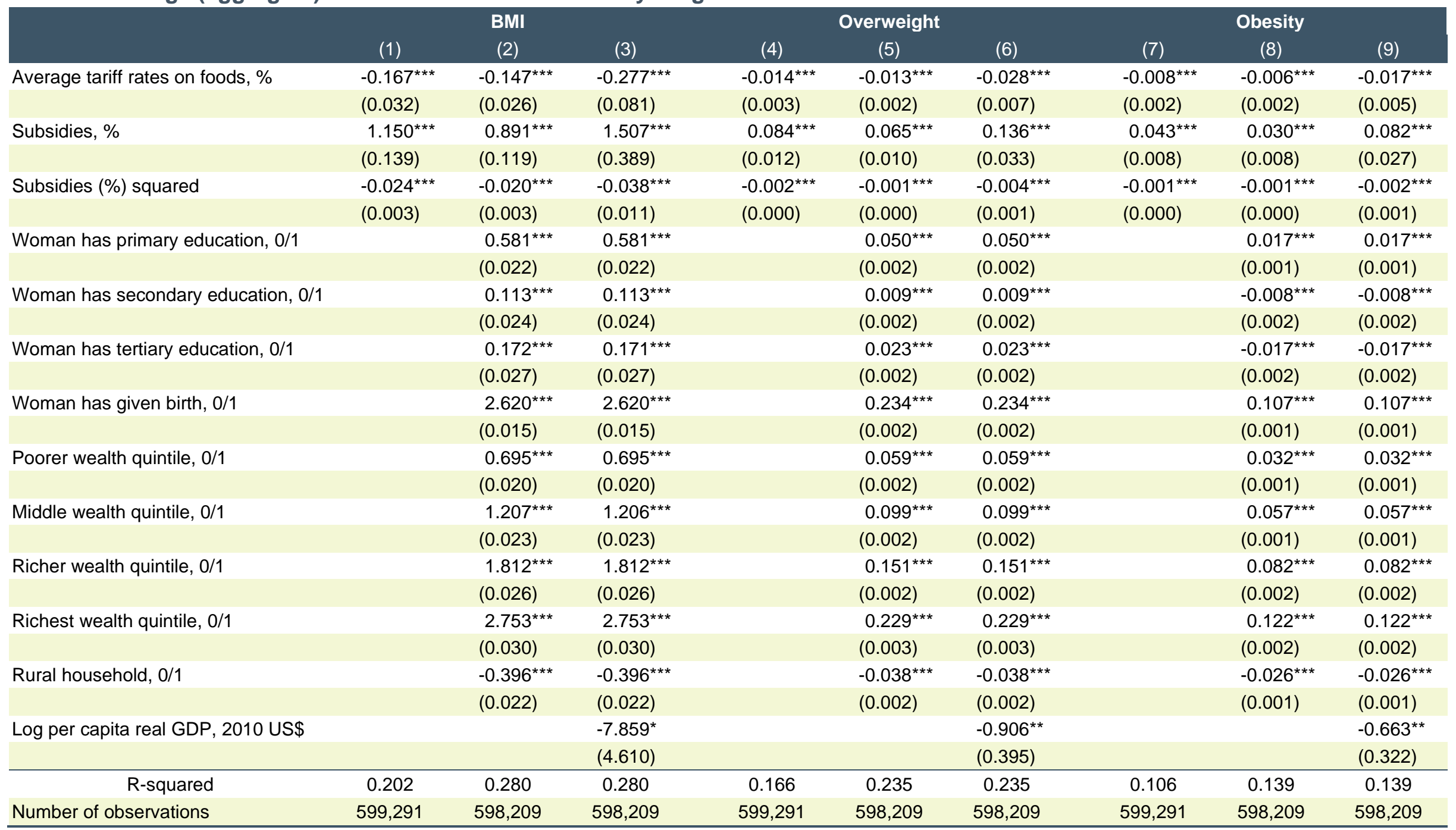

Notes: Country and year fixed effects are used in all models. Standard errors, clustered at each DHS cluster for each survey round, are given in parentheses. The base education outcome is no education, while the base wealth quintile is the poorest wealth quintile. BMI = Body mass index $\left(\mathrm{kg} / \mathrm{m}^{2}\right) .{ }^{*} \mathrm{p}<0.10,{ }^{* \star} \mathrm{p}<0.05,{ }^{\star \star \star} \mathrm{p}<0.01$. 
Although we are exploiting longitudinal variations in tariff rates on unhealthy diets so that time-invariant unobserved heterogeneities are innocuous, our estimates might not sufficiently inform causal inference due to endogeneity problems arising from omitted timevarying heterogeneities in the evolution of these policies. Despite this limitation, the associational evidence between fiscal policies and body weight can inform public health policies on the implication of international and domestic food policies on nutritional outcomes.

The first three columns in Table 2 show that a reduction in tariff rates on sugars and confectionery products is associated with an increase in body weight (BMI). The most conservative specification shows that a one percent reduction in tariff rates on sugars and confectionary foods is associated with an increase in BMI by $0.3 \mathrm{~kg} / \mathrm{m}^{2}$. The remaining results in Table 2 show similar relationships across alternative specifications and body weight outcomes.

Moreover, temporal increases in government spending on subsidies are associated with higher body weight outcomes. Those countries increasing their investment on subsidies, including subsidies on food, agricultural, and non-food items, are more likely to witness an increase in body weight. We note that our measure of government spending captures aggregate spending on subsidies, rather than the specific share of government expenditure on food subsidies. This is a potential limitation that could weaken the relationship between food subsidies and body weight. However, agricultural input and food subsidies remain major components of the overall subsidy spending in most countries.

Overall, the results in Table 2 suggest that government subsidies are strongly linked with nutrition and health outcomes. These patterns are consistent with previous micro-level pieces of evidence showing significant relationships between consumption of energy-dense subsidized food items and obesity rates (Asfaw 2006; Ecker et al. 2016). Intuitively, this implies that besides the common intention and objective of food and input subsidies - that is, reducing undernutrition and ensuring price stability - governments need to consider the adverse public health and nutritional implications of subsidies.

As discussed in Section 2, trade and government policies can affect nutritional outcomes through different channels and mechanisms. Furthermore, these policies are strongly correlated with other domestic policies and socioeconomic conditions of countries. For instance, government food policies are more likely to be correlated or respond to socioeconomic conditions of individuals and countries. Because of this, the strength of the relationships between food policies and body weight outcomes diminishes as we control for additional socioeconomic characteristics and macroeconomic conditions. For instance, the size of the estimates in all regressions substantially shrinks when we control for women's demographic and socioeconomic characteristics, suggesting that trade and food policies are related to these characteristics and their effects could be mediated through these channels.

In Table 3 we consider slightly different unhealthy foods - fats and oils - and report on the relationship between tariff rates on fats and oils and body weight. We follow similar specifications as in Table 2 and consider both a continuous body weight (BMI) outcome and binary indicators for overweight and obesity. This table shows that countries increasing tariff rates on fats and oils are more likely to experience a modest reduction in BMI and overweight and obesity rates. These relationships remain robust across all specifications and body weight outcomes. The size and implication of tariff rates on fats and oils are comparable to those based on tariff rates on sugars and confectionery food items. 
In Table 4 we generate an aggregate tariff rate on food items, which is averaged across several food items. We follow similar specifications and our results show similar patterns to Tables 2 and 3. Temporal dynamics in overall food tariff rates are associated with significant variation in body weight outcomes. As expected, the strength of the effect and relationships shrinks, compared to those in Tables 2 and 3, partly because we expect that tariff rates on unhealthy foods are likely to be more relevant to public health outcomes than aggregate food tariff rates. However, the fact that such a relationship exists across alternative tariff rates suggest that our results are reasonably robust.

The implication of the other covariates in Tables 2, 3, and 4 are consistent with previous evidence. For instance, household wealth is strongly and positively associated with body weight: wealthier women have higher BMI and higher probability of overweight and obesity (e.g. Siervo et al. 2006; Asfaw 2007; Ziraba, Fotso, and Ochako 2009; Abdulai 2010). Higher GDP per capita is also associated with higher BMI, overweight and obesity rates - although the coefficient on this variable is statistically insignificant in some of our specifications, which may be attributed to limited temporal variation. The positive associations between body weight outcomes and socioeconomic status is consistently observed in many macro and micro-level studies involving LMICs. For instance, many studies document an inverted-U relationship between economic growth and obesity (e.g., Kim, Symons, and Popkin 2004; Egger, Swinburn, and Amirul Islam 2012; Tafreschi 2015; Ameye and Swinnen 2019). This means that the relationship remains positive in most LMICs while turning to negative for HICs or as countries grow economically. Our sample covers LMICs and, hence, we are observing the first and positive part of the trend. Intuitively, such heterogenous relationships imply that strategies and campaigns that are proven effective in reducing the pandemic of overweight and obesity in developed countries may not necessarily curb unhealthy weight gains in LMICs.

Overall, the results in Tables 2, 3, and 4 consistently show that trade policies (reduction in tariff rates on unhealthy foods) and food policies (increase in government subsidies) may explain part of the increasing trends and cross-country differences in the distribution of body weight outcomes. This evidence is consistent with our hypothesis that a reduction in tariff rates on unhealthy foods can reduce the price of unhealthy foods and, hence, increase body weight. Similarly, food subsidies can increase consumer purchasing power, an effect that can increase demand for food. The economic affordability of such foods is expected to influence individuals' diets and hence nutritional outcomes (undernutrition and overnutrition).$^{5}$

\section{HETEROGENOUS RESPONSES AND ROBUSTNESS EXERCISES}

There are several important reasons why fiscal policies may have differential impacts for poorer and richer households. First, according to Engel's law and the Engel curves, poorer households allocate a larger share of their budget (income) to food consumption. This implies that fiscal policies, including taxes and subsidies, that affect the price of foods are likely to be more impactful on poorer households than on richer households. Second, recent studies show that healthy diets are more expensive than unhealthy diets (Headey and

\footnotetext{
${ }^{5}$ However, we lack access to these intermediate indicators and hence are unable to test these channels.
} 
Alderman 2019; Hirvonen et al. 2020), implying that poor households may not be able to afford healthy foods and, hence, rely on unhealthy foods (e.g., Ecker et al. 2016). Third, most subsidy programs, including those for food and for agricultural inputs, target poorer households. This implies that the potential dynamics of and reforms in these subsidies are likely to disproportionally affect poorer households.

To empirically test these hypotheses, we split our full sample across wealth quintiles and estimate the empirical specification in equation (1) for each wealth quintile. ${ }^{6}$ The results in Tables 5, 6, and 7 clearly show the differential implications of tariff rates on unhealthy foods for poor and for rich households. The relationship between tariff rates on unhealthy diets and body weight appears to be strong for the poorest households, while such relationships disappear for wealthier households. This pattern is consistent across alternative measures of tariff rates and across different unhealthy foods. The same tables show that the association between governments' expenditure on subsidies and body weight is strong and significant for poorer households, while such a relationship disappears for relatively richer households. The potential dynamics in tariff rates and government spending on subsidies appear to be unrelated to body weight outcomes of women in the wealthiest two quintiles.

We also probe the robustness of our results to alternative hypothesis related to the nature of the relationships and associated mechanisms. First, trade (food) policies or subsidy programs may endogenously respond to public health outcomes, implying potential reverse causality problems. Second, some trade policies or subsidy programs may need some time to influence domestic food systems and, hence, effects of these trade policies might not be immediate, partly because obesity rates are cumulative outcomes of the effects of underlying drivers. We, thus, lag our trade policies by one year and allow them to affect public health outcomes after one year, estimating a similar specification as in equation (1). This helps to address potential reverse causality concerns while also allowing delayed responses and impacts of trade policies.

The results in Tables A2, A3, and A4 in the Appendix show consistently similar relationships between dynamics in lagged trade policies and body weight outcomes. As expected, the strength of the associations between tariff rates on unhealthy foods and body weight outcomes shrink but remain statistically significant. The evidence that such relationships remain robust across alternative measures of trade and food policies as well as across several body weight outcomes and alternative empirical specification suggest that food policies are instrumentally relevant in food systems.

\section{CONCLUDING REMARKS}

This study investigates the implications of important food policies, mainly trade and government subsidies, on rising overweight and obesity rates in LMICs. We compiled several macro- and micro-level datasets that provide macro-level information on food policies as well as micro-level anthropometric measures.

\footnotetext{
${ }^{6}$ The DHS data provide indicators of household wealth in terms of wealth quintiles (Rutstein and Johnson 2004)
} 
Table 5: Heterogeneous implications of tariff rates on sugars and confectionery products on body weight outcomes

\begin{tabular}{|c|c|c|c|c|c|c|c|c|c|c|}
\hline & \multicolumn{2}{|c|}{ Poorest quintile } & \multicolumn{2}{|c|}{ Poorer quintile } & \multicolumn{2}{|c|}{ Middle quintile } & \multicolumn{2}{|c|}{ Richer quintile } & \multicolumn{2}{|c|}{ Richest quintile } \\
\hline & BMI & Overweight & BMI & Overweight & BMI & Overweight & BMI & Overweight & BMI & Overweight \\
\hline Average tariff rates on & $-0.617^{\star * \star}$ & $-0.050^{* * *}$ & $-0.531^{\star \star \star}$ & $-0.045^{\star \star \star}$ & $-0.265^{\star}$ & $-0.023^{\star}$ & 0.059 & -0.011 & -0.142 & -0.021 \\
\hline sugar \& confectioneries & $(0.130)$ & $(0.012)$ & $(0.138)$ & $(0.012)$ & $(0.144)$ & $(0.013)$ & $(0.147)$ & $(0.012)$ & $(0.174)$ & $(0.014)$ \\
\hline \multirow[t]{2}{*}{ Subsidies (\%) } & $2.499 * \star \star$ & $0.152^{\star \star \star}$ & $1.616^{\star \star \star}$ & $0.099 * \star \star$ & $0.832^{*}$ & 0.055 & 0.088 & 0.047 & 0.483 & $0.080^{\star \star}$ \\
\hline & $(0.394)$ & $(0.037)$ & $(0.405)$ & $(0.037)$ & $(0.425)$ & $(0.037)$ & $(0.434)$ & $(0.036)$ & $(0.502)$ & $(0.040)$ \\
\hline \multirow{2}{*}{ Subsidies (\%) squared } & $-0.056^{\star \star \star}$ & $-0.003^{\star \star *}$ & $-0.034^{\star \star \star}$ & $-0.002^{\star \star}$ & -0.013 & -0.001 & 0.005 & -0.001 & -0.012 & $-0.002^{*}$ \\
\hline & $(0.010)$ & $(0.001)$ & $(0.010)$ & $(0.001)$ & $(0.010)$ & $(0.001)$ & $(0.011)$ & $(0.001)$ & $(0.012)$ & $(0.001)$ \\
\hline R-squared & 0.310 & 0.239 & 0.302 & 0.248 & 0.296 & 0.254 & 0.273 & 0.234 & 0.224 & 0.193 \\
\hline Number of observations & 115,450 & 115,450 & 121,445 & 121,445 & 120,987 & 120,987 & 118,672 & 118,672 & 121,655 & 121,655 \\
\hline
\end{tabular}

Notes: Demographic, socio-economic, and macroeconomic controls, country, and year fixed effects are used in all models. Standard errors, clustered at each DHS cluster for each survey round, are given in parentheses. $\mathrm{BMI}=$ Body mass index $\left(\mathrm{kg} / \mathrm{m}^{2}\right) .{ }^{*} \mathrm{p}<0.10,{ }^{* *} \mathrm{p}<0.05,{ }^{* * *} \mathrm{p}<0.01$.

Table 6: Heterogeneous implications of tariff rates on fats and oils on body weight outcomes

\begin{tabular}{|c|c|c|c|c|c|c|c|c|c|c|}
\hline & \multicolumn{2}{|c|}{ Poorest quintile } & \multicolumn{2}{|c|}{ Poorer quintile } & \multicolumn{2}{|c|}{ Middle quintile } & \multicolumn{2}{|c|}{ Richer quintile } & \multicolumn{2}{|c|}{ Richest quintile } \\
\hline & BMI & Overweight & BMI & Overweight & BMI & Overweight & BMI & Overweight & BMI & Overweight \\
\hline Average tariff rates on & $-0.764^{\star \star \star}$ & $-0.061^{\star \star \star}$ & $-0.657^{\star \star \star}$ & $-0.055^{\star \star \star}$ & $-0.328^{*}$ & $-0.029 *$ & 0.073 & -0.014 & -0.176 & -0.026 \\
\hline fats and oils & $(0.161)$ & $(0.015)$ & $(0.171)$ & $(0.015)$ & $(0.178)$ & $(0.016)$ & $(0.183)$ & $(0.015)$ & $(0.215)$ & $(0.017)$ \\
\hline \multirow[t]{2}{*}{ Subsidies (\%) } & $2.735^{\star \star \star}$ & $0.171^{\star \star \star}$ & $1.820^{\star \star \star}$ & $0.116^{\star \star \star}$ & $0.934^{*}$ & 0.064 & 0.065 & 0.051 & 0.537 & $0.088^{\star \star}$ \\
\hline & $(0.441)$ & $(0.042)$ & $(0.455)$ & $(0.042)$ & $(0.478)$ & $(0.042)$ & $(0.488)$ & $(0.040)$ & $(0.565)$ & $(0.045)$ \\
\hline \multirow[t]{2}{*}{ Subsidies (\%) squared } & $-0.066^{\star \star *}$ & $-0.004^{\star \star \star}$ & $-0.042^{* \star *}$ & $-0.003^{\star *}$ & -0.017 & -0.001 & 0.006 & -0.001 & -0.014 & $-0.002^{*}$ \\
\hline & $(0.011)$ & $(0.001)$ & $(0.012)$ & $(0.001)$ & $(0.013)$ & $(0.001)$ & $(0.013)$ & $(0.001)$ & $(0.015)$ & $(0.001)$ \\
\hline R-squared & 0.310 & 0.239 & 0.302 & 0.248 & 0.296 & 0.254 & 0.273 & 0.234 & 0.224 & 0.193 \\
\hline Number of observations & 115,450 & 115,450 & 121,445 & 121,445 & 120,987 & 120,987 & 118,672 & 118,672 & 121,655 & 121,655 \\
\hline
\end{tabular}

Notes: Demographic, socio-economic, and macroeconomic controls, country, and year fixed effects are used in all models. Standard errors, clustered at each DHS cluster for each survey round, are given in parentheses. BMI = Body mass index $\left(\mathrm{kg} / \mathrm{m}^{2}\right) .{ }^{*} \mathrm{p}<0.10,{ }^{* *} \mathrm{p}<0.05,{ }^{* \star *} \mathrm{p}<0.01$. 
Table 7: Heterogenous implications of tariff rates on all foods on body weight outcomes

\begin{tabular}{|c|c|c|c|c|c|c|c|c|c|c|}
\hline & \multicolumn{2}{|c|}{ Poorest quintile } & \multicolumn{2}{|c|}{ Poorer quintile } & \multicolumn{2}{|c|}{ Middle quintile } & \multicolumn{2}{|c|}{ Richer quintile } & \multicolumn{2}{|c|}{ Richest quintile } \\
\hline & BMI & Overweight & BMI & Overweight & BMI & Overweight & BMI & Overweight & BMI & Overweight \\
\hline Average tariff rates on & $-0.660^{\star \star *}$ & $-0.053^{\star \star \star}$ & $-0.568^{\star \star \star}$ & $-0.048^{\star \star \star}$ & $-0.284^{*}$ & $-0.025^{\star}$ & 0.063 & -0.012 & -0.152 & -0.022 \\
\hline foods & $(0.139)$ & $(0.013)$ & $(0.148)$ & $(0.013)$ & $(0.154)$ & $(0.014)$ & $(0.158)$ & $(0.013)$ & $(0.186)$ & $(0.015)$ \\
\hline \multirow[t]{2}{*}{ Subsidies, \% } & $3.921 * \star \star$ & $0.266^{\star \star \star}$ & 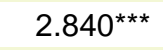 & $0.202^{\star \star \star}$ & $1.443^{\star}$ & $0.108^{\star}$ & -0.049 & 0.072 & 0.810 & $0.128^{*}$ \\
\hline & $(0.683)$ & $(0.064)$ & $(0.715)$ & $(0.065)$ & $(0.748)$ & $(0.065)$ & $(0.764)$ & $(0.064)$ & $(0.890)$ & $(0.071)$ \\
\hline \multirow[t]{2}{*}{ Subsidies (\%) squared } & $-0.104^{\star * *}$ & $-0.007^{\star \star \star}$ & $-0.075^{\star \star \star}$ & $-0.005^{\star \star \star}$ & -0.034 & -0.003 & 0.009 & -0.002 & -0.023 & $-0.003^{*}$ \\
\hline & $(0.019)$ & $(0.002)$ & $(0.020)$ & $(0.002)$ & $(0.021)$ & $(0.002)$ & $(0.022)$ & $(0.002)$ & $(0.025)$ & $(0.002)$ \\
\hline R-squared & 0.310 & 0.239 & 0.302 & 0.248 & 0.296 & 0.254 & 0.273 & 0.234 & 0.224 & 0.193 \\
\hline Number of observations & 115,450 & 115,450 & 121,445 & 121,445 & 120,987 & 120,987 & 118,672 & 118,672 & 121,655 & 121,655 \\
\hline
\end{tabular}

Notes: Demographic, socio-economic, and macroeconomic controls, country, and year fixed effects are used in all models. Standard errors, clustered at each DHS cluster for each survey round, are given in parentheses. BMI $=$ Body mass index $\left(\mathrm{kg} / \mathrm{m}^{2}\right) .{ }^{*} \mathrm{p}<0.10,{ }^{* *} \mathrm{p}<0.05,{ }^{* *} \mathrm{p}<0.01$. 
Our findings show significant relationships between trade (food) policies and women's body weight outcomes. More specifically, temporal dynamics in tariff rates on unhealthy and energy-dense foods are significantly and negatively associated with body weight outcomes. Conditional on other observable and time-invariant unobservable factors, an increase in tariff rates on sugar and confectionary foods is associated with a reduction in overweight and obesity rates. Similarly, countries experiencing an increase in tariff rates on fats and oils are more likely to experience a reduction in average body weight. On the other hand, an increase in government subsidy rates (as a share of annual government expenditure) are significantly associated with higher overweight and obesity rates. We detect such robust relationships across alternative specifications, both using contemporaneous as well as lagged values of these policies. More importantly, we also find that the effects of these fiscal policies appear to be more pronounced among poorer households. This is intuitive because relatively poorer households are more likely to spend a larger share of their budget on food consumption or are more likely to rely on cheaper, but less healthy foods. These findings contribute to evolving debates on the role of fiscal policies and instruments to combat obesity and associated NCDs (WHO 2015; Thow et al. 2018).

These findings have important implications for informing public health policies in LMICs, which are experiencing an unprecedented rise in overweight and obesity rates. As most LMICs are experiencing a significant increase in population, trade and food policies remain important instruments that can shape food systems. The robust relationship between tariff rates on unhealthy foods and body weight suggests that these policies can be powerful instruments to combat obesity and associated NCDs. Furthermore, this implies that governments should consider making these types of fiscal policies nutrition-sensitive.

Recently, economists and policymakers began considering health costs in the costbenefit analysis of new trade agreements (UNDP 2013). However, trade policies are complex and involve transnational agreements and initiatives. To lessen the adverse effects of trade policies, most countries have focused on domestic policies to influence the consumption and prices of unhealthy foods. For instance, many governments have enacted alternative forms of taxes on energy-dense foods (e.g., Thow et al. 2011; Zhen et al. 2014; Cawley and Frisvold 2015; Nakhimovsky et al. 2016: Roache and Gostin 2017; Alsukait et al. 2020). Many LMICs have government sponsored government food and agricultural subsidies and some of these programs are not nutrition-sensitive. Our findings reinforce that government subsidies may have adverse public health implications. The design of subsidy programs should be modified in their targeting or modalities to address their adverse public health implications. Some countries have already started reforming their subsidy programs, particularly through a gradual shift from direct subsidization of goods towards smart, targeted cash transfers (Sdralevich et al. 2014). 


\section{REFERENCES}

Abay, Kibrom A., and Mulubrhan Amare. 2018. "Night Light Intensity and Women's Body Weight: Evidence from Nigeria." Economics and Human Biology 31: 238-48. https://doi.org/10.1016/j.ehb.2018.09.001.

Abay, Kibrom A., Hosam Ibrahim, and Clemens Breisinger. 2020. "Food Policies and Their Implications on Overweight and Obesity Trends in Selected Countries in Near East and North Africa Region." IFPRI MENA Working Paper RP.

Abdalla, Moustafa, and Sherine Al-Shawarby. 2018. "The Tamween Food Subsidy System in Egypt." In The 1.5 Billion People Question: Food, Vouchers, or Cash Transfers?, edited by Harold Alderman, Ugo Gentilini, and Ruslan Yemtsov, 107-50. Washington DC.

Abdulai, Awudu. 2010. "Socio-Economic Characteristics and Obesity in Underdeveloped Economies: Does Income Really Matter?" Applied Economics 42 (2): 157-69. https://doi.org/10.1080/00036840701604313.

Allcott, Hunt, Benjamin, Lockwood, and Dimitry Taubinsky. 2019. "Should we tax soda? An overview of theory and evidence." Journal of Economic Perspectives 33 (3) 202-227.

Alderman, Harold, Ugo Gentilini, and Ruslan Yemtsov. 2018. The 1.5 Billion People Question: Food, Vouchers, or Cash Transfers? Washington, DC: World Bank Group. https://doi.org/10.1596/978-1-4648-1087-9.

Alsukait, Reem, Sara Bleich, Parke Wilde, Gitanjali Singh, and Sara Folta. 2020. "Sugary Drink Excise Tax Policy Process and Implementation: Case Study from Saudi Arabia." Food Policy 90 (February 2019): 101789. https://doi.org/10.1016/j.foodpol.2019.101789.

Ameye, Hannah, and Johan Swinnen. 2019. "Obesity, Income and Gender: The Changing Global Relationship." LICOS Centre for Institutions and Economic Performance, no. Discussion Paper 415/2019.

Asfaw, Abay. 2006. "The Role of Food Price Policy in Determining the Prevalence of Obesity: Evidence from Egypt." Review of Agricultural Economics 28 (3): 305-12. https://doi.org/10.1111/j.1467-9353.2006.00291.x.

- 2007. "Do Government Food Price Policies Affect the Prevalence of Obesity? Empirical Evidence from Egypt." World Development 35 (4): 687-701. https://doi.org/10.1016/j.worlddev.2006.05.005.

Baker, Phillip, Sharon Friel, Ashley Schram, and Ron Labonte. 2016. "Trade and Investment Liberalization, Food Systems Change and Highly Processed Food Consumption: A Natural Experiment Contrasting the SoftDrink Markets of Peru and Bolivia." Globalization and Health 12 (1): 1-13. https://doi.org/10.1186/s12992016-0161-0.

Baker, Phillip, Alexandra Jones, and Anne Marie Thow. 2018. "Accelerating the Worldwide Adoption of SugarSweetened Beverage Taxes: Strengthening Commitment and Capacity: Comment on 'The Untapped Power of Soda Taxes: Incentivizing Consumers, Generating Revenue, and Altering Corporate Behavior.'” International Journal of Health Policy and Management 7 (5): 474-78. https://doi.org/10.15171/ijhpm.2017.127.

Barrett, Christopher B. 2002. "Food Security and Food Assistance Programs." Handbook of Agricultural Economics 2 (B): 2103-90. https://doi.org/10.1016/S1574-0072(02)10027-2.

Blouin, Chantal, Mickey Chopra, and Rolph van der Hoeven. 2009. "Trade and Social Determinants of Health." The Lancet 373 (9662): 502-7. https://doi.org/10.1016/S0140-6736(08)61777-8.

Cawley, John, and David Frisvold. 2015. "The Incidence of Taxes on Sugar-Sweetened Beverages: The Case of Berkeley, California." NBER Working Paper Series August (Working Paper 21465): 1689-99. https://doi.org/10.1017/CBO9781107415324.004.

Costa-Font, Joan, and Núria Mas. 2016. "'Globesity'? The Effects of Globalization on Obesity and Caloric Intake." Food Policy 64: 121-32. https://doi.org/10.1016/j.foodpol.2016.10.001.

DHS. 2018. "Demographic and Health Surveys (Various) [Datasets]." ICF International 1988-2017. Calverton, Maryland.

Donaldson, Elisabeth. 2015. "Advocating for Sugar-Sweetened Beverage Taxation: A Case Study of Mexico." Johns Hopkins Bloomberg School of Public Health. http://www.jhsph.edu/departments/health-behavior-andsociety/_pdf/Advocating_For_Sugar_Sweetened_Beverage_Taxation.pdf.

Ecker, Olivier, Perrihan Al-Riffai, Clemens Breisinger, and Rawia El-Batrawy. 2016. Nutrition and Economic Development: Exploring Egypt's Exceptionalism and the Role of Food Subsidies. International Food Policy Research Institute (IFPRI). Washington, DC: IFPRI.

Egger, Garry, Boyd Swinburn, and F. M. Amirul Islam. 2012. "Economic Growth and Obesity: An Interesting Relationship with World-Wide Implications." Economics and Human Biology 10 (2): 147-53. https://doi.org/10.1016/j.ehb.2012.01.002.

Friel, S., L. Hattersley, W. Snowdon, A. M. Thow, T. Lobstein, D. Sanders, S. Barquera, et al. 2013. "Monitoring the Impacts of Trade Agreements on Food Environments." Obesity Reviews 14 (S1): 120-34.

https://doi.org/10.1111/obr.12081. 
Harpham, T., H. Reed, M. Montgomery, D. Satterthwaite, C. Moser, and B. Cohen. 2003. "Mortality and Morbidity: Is City Life Good for Your Health?" In Cities Transformed Demographic Change and Its Implications in the Developing World, edited by Mark R. Montgomery, Richard Stren, Barney Cohen, and Holly E. Reed, 1st ed., 259-300. New York: Earthscan, Routledge.

Hawkes, Corinna. 2005. "The Role of Foreign Direct Investment in the Nutrition Transition." Public Health Nutrition 8 (4): 357-65. https://doi.org/10.1079/phn2004706.

_ 2006. "Uneven Dietary Development: Linking the Policies and Processes of Globalization with the Nutrition Transition, Obesity and Diet-Related Chronic Diseases." Globalization and Health 2: 1-18. https://doi.org/10.1186/1744-8603-2-4.

Hawkes, Corinna, Mickey Chopra, and Sharon Friel. 2009. "Globalization, Trade, and the Nutrition Transition." In Globalization and Health: Pathways, Evidence and Policy, edited by Ronald Labonte, Ted Schrecker, Corinne Packer, and Vivien Runnels, 235-62. New York: Routledge.

Hawkes, Corinna, Sharon Friel, Tim Lobstein, and Tim Lang. 2012. "Linking Agricultural Policies with Obesity and Noncommunicable Diseases: A New Perspective for a Globalising World." Food Policy 37 (3): 343-53. https://doi.org/10.1016/j.foodpol.2012.02.011.

Headey, Derek D, and Harold H Alderman. 2019. "The Relative Caloric Prices of Healthy and Unhealthy Foods Differ Systematically across Income Levels and Continents." The Journal of Nutrition, 1-14. https://doi.org/10.1093/jn/nxz158.

Hirvonen, Kalle, Yan Bai, Derek Headey, and William A. Masters. 2020. "Affordability of the EAT-Lancet Reference Diet: A Global Analysis." The Lancet Global Health 8 (1): e59-66. https://doi.org/10.1016/S2214109X(19)30447-4.

Jensen, Robert T., and Nolan H. Miller. 2011. "Do Consumer Price Subsidies Really Improve Nutrition?" Review of Economics and Statistics 93 (4): 1205-23. https://doi.org/10.1162/REST_a_00118.

Kilpi, Fanny, Laura Webber, Abdulrahman Musaigner, Amina Aitsi-Selmi, Tim Marsh, Ketevan Rtveladze, Klim McPherson, and Martin Brown. 2014. "Alarming Predictions for Obesity and Non-Communicable Diseases in the Middle East." Public Health Nutrition 17 (5): 1078-86. https://doi.org/10.1017/S1368980013000840.

Kim, Soowon, Michael Symons, and Barry M. Popkin. 2004. "Contrasting Socioeconomic Profiles Related to Healthier Lifestyles in China and the United States." American Journal of Epidemiology 159 (2): 184-91. https://doi.org/10.1093/aje/kwh006.

Kochar, Anjini. 2005. "Can Targeted Food Programs Improve Nutrition? An Empricial Analysis of India's Public Distribution System." Economic Development and Cultural Change 54 (1): 203-35. https://doi.org/10.1086/431260.

Krivonos, Ekaterina, and Lena Kuhn. 2019. "Trade and Dietary Diversity in Eastern Europe and Central Asia 2 ." Food Policy, no. December 2018: 101767. https://doi.org/10.1016/j.foodpol.2019.101767.

Löfgren, Hans, and Moataz El-Said. 2001. "Food Subsidies in Egypt: Reform Options, Distribution and Welfare." Food Policy 26 (1): 65-83. https://doi.org/10.1016/S0306-9192(00)00030-0.

Miranda, J. Jaime, Tonatiuh Barrientos-Gutiérrez, Camila Corvalan, Adnan A. Hyder, Maria Lazo-Porras, Tolu Oni, and Jonathan C.K. Wells. 2019. "Understanding the Rise of Cardiometabolic Diseases in Low- and Middle-Income Countries." Nature Medicine 25 (11): 1667-79. https://doi.org/10.1038/s41591-019-0644-7.

Monda, Keri L., Penny Gordon-Larsen, June Stevens, and Barry M. Popkin. 2007. "China's Transition: The Effect of Rapid Urbanization on Adult Occupational Physical Activity." Social Science \& Medicine 64 (4): 858-70. https://doi.org/10.1016/j.socscimed.2006.10.019.

Nakhimovsky, Sharon S., Andrea B. Feigl, Carlos Avila, Gael O'Sullivan, Elizabeth MacGregor-Skinner, and Mark Spranca. 2016. "Taxes on Sugar-Sweetened Beverages to Reduce Overweight and Obesity in MiddleIncome Countries: A Systematic Review." PLOS ONE 11 (9): 1-22. https://doi.org/10.1371/journal.pone.0163358.

Ng, Marie, Tom Fleming, Margaret Robinson, Blake Thomson, Nicholas Graetz, Christopher Margono, Erin C. Mullany, et al. 2014. "Global, Regional, and National Prevalence of Overweight and Obesity in Children and Adults during 1980-2013: A Systematic Analysis for the Global Burden of Disease Study 2013." The Lancet 384 (9945): 766-81. https://doi.org/10.1016/S0140-6736(14)60460-8.

Popkin, Barry M. 1999. "Urbanization, Lifestyle Changes and the Nutrition Transition." World Development 27 (11): 1905-16. https://doi.org/10.1016/S0305-750X(99)00094-7.

Roache, Sarah A., and Lawrence O. Gostin. 2017. "The Untapped Power of Soda Taxes: Incentivizing Consumers, Generating Revenue, and Altering Corporate Behavior." International Journal of Health Policy and Management 6 (9): 489-93. https://doi.org/10.15171/ijhpm.2017.69.

Rutstein, Shea Oscar, and Kiersten Johnson. 2004. "The DHS Wealth Index." DHS Comparative Reports 6.

Schram, Ashley, Ronald Labonte, Phillip Baker, Sharon Friel, Aaron Reeves, and David Stuckler. 2015. "The Role of Trade and Investment Liberalization in the Sugar-Sweetened Carbonated Beverages Market: A 
Natural Experiment Contrasting Vietnam and the Philippines." Globalization and Health 11 (1): 1-13. https://doi.org/10.1186/s12992-015-0127-7.

Sdralevich, Carlo, Randa Sab, Younes Zouhar, and Giorgia Albertin. 2014. Subsidy Reform in the Middle East and North Africa. Recent Progress and Challenges Ahead. International Monetary Fund, Middle East and Central Asia Department. Washington DC. https://doi.org/10.5089/9781498350433.087.

Shankar, Bhavani. 2017. "The Influence of Agricultural, Trade and Food Policies on Diets." Trade Policy Technical Notes: Trade and Food Security, no. 18. http://www.fao.org/3/a-i8190e.pdf.

Shekar, Meera, and Barry Popkin, eds. 2020. Obesity: Health and Economic Consequences of an Impending Global Challenge. Washington, DC: World Bank Group.

Siervo, Mario, P. Grey, O. A. Nyan, and A. M. Prentice. 2006. "Urbanization and Obesity in The Gambia: A Country in the Early Stages of the Demographic Transition." European Journal of Clinical Nutrition 60 (4): 455-63. https://doi.org/10.1038/sj.ejcn.1602337.

Snowdon, W., and A. M. Thow. 2013. "Trade Policy and Obesity Prevention: Challenges and Innovation in the Pacific Islands." Obesity Reviews 14 (S2): 150-58. https://doi.org/10.1111/obr.12090.

Tafreschi, Darjusch. 2015. "The Income Body Weight Gradients in the Developing Economy of China." Economics and Human Biology 16: 115-34. https://doi.org/10.1016/j.ehb.2014.02.001.

Thow, Anne Marie, Shauna M. Downs, Christopher Mayes, Helen Trevena, Temo Waqanivalu, and John Cawleye. 2018. "Fiscal Policy to Improve Diets and Prevent Noncommunicable Diseases: From Recommendations to Action." Bulletin of the World Health Organization 96 (3): 201-10. https://doi.org/10.2471/BLT.17.195982.

Thow, Anne Marie, and Corinna Hawkes. 2009. "The Implications of Trade Liberalization for Diet and Health: A Case Study from Central America." Globalization and Health 5: 1-15. https://doi.org/10.1186/1744-8603-5-5.

Thow, Anne Marie, Peter Heywood, Jimaima Schultz, Christine Quested, Stephen Jan, and Stephen Colagiuri. 2011. "Trade and the Nutrition Transition: Strengthening Policy for Health in the Pacific." Ecology of Food and Nutrition 50 (1): 18-42. https://doi.org/10.1080/03670244.2010.524104.

Thow, Anne Marie, Christine Quested, Lisa Juventin, Russ Kun, A. Nisha Khan, and Boyd Swinburn. 2011. "Taxing Soft Drinks in the Pacific: Implementation Lessons for Improving Health." Health Promotion International 26 (1): 55-64. https://doi.org/10.1093/heapro/daq057.

Timmer, C. P., W. P. Falcon, and S. R. Pearson. 1983. "Food Policy Analysis." Food Policy Analysis. https://fsilive.s3.us-west-1.amazonaws.com/s3fs-public/Food_Policy_Analysis.pdf.

UNDP. 2013. "Trade, Trade Agreements and Non-Communicable Disease in the Pacific Islands. Intersections, Lessons Leaned, Challenges and Ways Forward." In C-POND, SPC, UNDP, WHO. Suva: UNDP Pacific Centre.

WHO. 2015. "Fiscal Policies for Diet and the Prevention of Noncommunicable Diseases." Technical Meeting Report WHO Regional Office for Europe, no. May: 36. http://www.who.int/dietphysicalactivity/publications/fiscal-policies-diet-prevention/en/.

World Bank. 2019. "World Development Indicators (WDI)." DataBank. 2019. https://databank.worldbank.org/source/world-development-indicators.

WTO. 2019. "Integrated Database (IDB)." Tariff Download Facility. 2019. http://tariffdata.wto.org/ReportersAndProducts.aspx.

Zhen, Chen, Eric A. Finkelstein, James M. Nonnemaker, Shawn A. Karns, and Jessica E. Todd. 2014. "Predicting the Effects of Sugar-Sweetened Beverage Taxes on Food and Beverage Demand in a Large Demand System." American Journal of Agricultural Economics 96 (1): 1-25. https://doi.org/10.1093/ajae/aat049.

Ziraba, Abdhalah K., Jean C. Fotso, and Rhoune Ochako. 2009. "Overweight and Obesity in Urban Africa: A Problem of the Rich or the Poor?" BMC Public Health 9: 1-9. https://doi.org/10.1186/1471-2458-9-465. 


\section{APPENDIX}

Table A1: Body-mass Index and tariff rates for food imports for study countries, average

\begin{tabular}{|c|c|c|c|c|c|}
\hline & \multicolumn{5}{|c|}{ Tariffs } \\
\hline & $\begin{array}{c}\text { BMI, } \\
\text { non-pregnant } \\
\text { women, average }\end{array}$ & $\begin{array}{l}\text { Sugars and } \\
\text { confectionery } \\
\text { products }\end{array}$ & $\begin{array}{c}\text { Fats } \\
\text { and oils }\end{array}$ & Foods & Observations \\
\hline Armenia & 25.4 & 8.15 & 6.60 & 9.17 & 5,898 \\
\hline Bangladesh & 21.3 & 20.07 & 10.46 & 19.09 & 27,839 \\
\hline Benin & 23.0 & 11.25 & 10.60 & 14.56 & 31,738 \\
\hline Burkina Faso & 21.4 & 11.25 & 10.72 & 14.62 & 7,624 \\
\hline Burundi & 21.3 & 32.19 & 11.59 & 25.50 & 4,104 \\
\hline Cambodia & 22.1 & 7.00 & 8.12 & 15.66 & 11,480 \\
\hline Colombia & 25.0 & 16.75 & 15.90 & 22.27 & 49,637 \\
\hline Congo, Democratic Republic & 21.5 & 13.13 & 12.07 & 13.40 & 3,988 \\
\hline Cote d'Ivoire & 22.9 & 11.25 & 10.72 & 14.60 & 4,309 \\
\hline Dominican Republic & 25.9 & 13.10 & 5.15 & 14.53 & 9,180 \\
\hline Egypt & 29.4 & 11.69 & 4.49 & 11.28 & 55,890 \\
\hline Ethiopia & 20.3 & 8.75 & 17.01 & 20.93 & 14,721 \\
\hline Guatemala & 26.0 & 11.67 & 5.52 & 10.66 & 24,193 \\
\hline Honduras & 25.8 & 13.14 & 5.63 & 12.81 & 21,090 \\
\hline Jordan & 29.2 & 8.23 & 9.41 & 12.74 & 10,596 \\
\hline Kenya & 23.3 & 33.68 & 11.64 & 27.19 & 14,422 \\
\hline Lesotho & 25.2 & 4.49 & 7.66 & 8.45 & 7,175 \\
\hline Malawi & 22.6 & 17.74 & 12.31 & 17.52 & 14,960 \\
\hline Maldives & 24.8 & 13.13 & 14.17 & 15.16 & 5,602 \\
\hline Mali & 22.4 & 11.25 & 10.55 & 14.55 & 18,228 \\
\hline Mozambique & 22.7 & 9.06 & 9.50 & 14.62 & 12,197 \\
\hline Namibia & 23.4 & 3.81 & 7.78 & 9.77 & 13,608 \\
\hline Nepal & 21.5 & 14.38 & 9.66 & 12.28 & 5,847 \\
\hline Nigeria & 22.8 & 14.23 & 16.28 & 16.06 & 70,639 \\
\hline Peru & 25.6 & 5.84 & 3.52 & 5.84 & 91,291 \\
\hline Rwanda & 23.0 & 34.12 & 11.64 & 27.16 & 6,690 \\
\hline South Africa & 28.0 & 10.41 & 7.58 & 8.46 & 3,378 \\
\hline Togo & 23.5 & 11.25 & 10.72 & 14.60 & 4,825 \\
\hline Uganda & 22.8 & 34.12 & 11.64 & 27.24 & 6,049 \\
\hline Zambia & 22.7 & 22.00 & 14.09 & 20.14 & 23,269 \\
\hline Zimbabwe & 24.2 & 14.47 & 10.32 & 22.37 & 17,742 \\
\hline Total & 24.4 & 13.18 & 9.76 & 14.76 & 598,209 \\
\hline
\end{tabular}

Source: Demographic Health Surveys and the World Trade Organization (DHS 2018; WTO 2019). 
Table A2: Lagged tariff rates on sugars and confectionery products and body weight outcomes

\begin{tabular}{|c|c|c|c|c|c|c|c|c|c|}
\hline & \multicolumn{3}{|c|}{ BMI } & \multicolumn{3}{|c|}{ Overweight } & \multicolumn{3}{|c|}{ Obesity } \\
\hline & (1) & (2) & (3) & (4) & (5) & (6) & (7) & (8) & (9) \\
\hline Lagged tariff rates on sugars & $-0.186^{\star \star \star}$ & $-0.148^{\star \star \star}$ & $-0.148^{\star * *}$ & $-0.014^{\star \star \star}$ & $-0.011^{\star \star \star}$ & $-0.011^{\star \star \star}$ & $-0.010 * \star \star$ & $-0.008^{\star \star \star}$ & $-0.008^{\star \star \star}$ \\
\hline and confectionery products & $(0.026)$ & $(0.021)$ & $(0.021)$ & $(0.002)$ & $(0.002)$ & $(0.002)$ & $(0.002)$ & $(0.001)$ & $(0.001)$ \\
\hline Demographic characteristics & No & Yes & Yes & No & Yes & Yes & No & Yes & Yes \\
\hline Socioeconomic characteristics & No & Yes & Yes & No & Yes & Yes & No & Yes & Yes \\
\hline Macroeconomic variables & No & No & Yes & No & No & Yes & No & No & Yes \\
\hline R-squared & 0.142 & 0.236 & 0.236 & 0.112 & 0.193 & 0.193 & 0.058 & 0.098 & 0.098 \\
\hline Number of observations & 413,221 & 412,269 & 412,269 & 413,221 & 412,269 & 412,269 & 413,221 & 412,269 & 412,269 \\
\hline
\end{tabular}

Notes: Country and year fixed effects are used in all models. Standard errors, clustered at each DHS cluster for each survey round, are given in parentheses. BMI $=$ Body mass index $\left(\mathrm{kg} / \mathrm{m}^{2}\right) .{ }^{*} \mathrm{p}<0.10$, ** $p<0.05,{ }^{* *} p<0.01$.

Table A3: Lagged tariff rates on fats and oils and body weight outcomes

\begin{tabular}{|c|c|c|c|c|c|c|c|c|c|}
\hline & \multicolumn{3}{|c|}{ BMI } & \multicolumn{3}{|c|}{ Overweight } & \multicolumn{3}{|c|}{ Obesity } \\
\hline & (1) & (2) & (3) & (4) & (5) & (6) & (7) & (8) & (9) \\
\hline \multirow[t]{2}{*}{ Lagged tariff rates on fats and oils } & $-0.087^{\star \star \star}$ & $-0.144^{\star \star \star}$ & $-0.144^{\star \star \star}$ & $-0.009 * \star \star$ & $-0.013^{\star \star \star}$ & $-0.013^{\star \star \star}$ & $-0.005^{\star \star \star}$ & $-0.008^{\star \star \star}$ & $-0.008^{\star \star *}$ \\
\hline & $(0.012)$ & $(0.010)$ & $(0.010)$ & $(0.001)$ & $(0.001)$ & $(0.001)$ & $(0.001)$ & $(0.001)$ & $(0.001)$ \\
\hline Demographic characteristics & No & Yes & Yes & No & Yes & Yes & No & Yes & Yes \\
\hline Socioeconomic characteristics & No & Yes & Yes & No & Yes & Yes & No & Yes & Yes \\
\hline Macroeconomic variables & No & No & Yes & No & No & Yes & No & No & Yes \\
\hline R-squared & 0.142 & 0.236 & 0.236 & 0.112 & 0.193 & 0.193 & 0.058 & 0.098 & 0.098 \\
\hline Number of observations & 413,221 & 412,269 & 412,269 & 413,221 & 412,269 & 412,269 & 413,221 & 412,269 & 412,269 \\
\hline
\end{tabular}

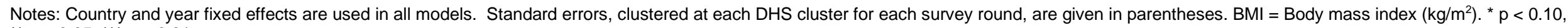
$\star \star p<0.05,{ }^{* \star \star} p<0.01$. 
Table A4: Lagged (aggregate) tariff rates on food and body weight outcomes

\begin{tabular}{|c|c|c|c|c|c|c|c|c|c|}
\hline & \multicolumn{3}{|c|}{ BMI } & \multicolumn{3}{|c|}{ Overweight } & \multicolumn{3}{|c|}{ Obesity } \\
\hline & (1) & (2) & (3) & (4) & (5) & (6) & (7) & (8) & (9) \\
\hline \multirow[t]{2}{*}{ Lagged tariff rates on food } & $-0.159 * \star \star$ & $-0.137^{\star \star \star}$ & $-0.137^{\star \star \star}$ & $-0.013^{\star \star \star}$ & $-0.012^{\star \star \star}$ & $-0.012^{\star \star *}$ & $-0.007 * * *$ & $-0.006^{\star \star \star}$ & $-0.006^{\star \star *}$ \\
\hline & $(0.014)$ & $(0.012)$ & $(0.012)$ & $(0.001)$ & $(0.001)$ & $(0.001)$ & $(0.001)$ & $(0.001)$ & $(0.001)$ \\
\hline Demographic characteristics & No & Yes & Yes & No & Yes & Yes & No & Yes & Yes \\
\hline Socioeconomic characteristics & No & Yes & Yes & No & Yes & Yes & No & Yes & Yes \\
\hline Macroeconomic variables & No & No & Yes & No & No & Yes & No & No & Yes \\
\hline R-squared & 0.142 & 0.236 & 0.236 & 0.112 & 0.193 & 0.193 & 0.058 & 0.098 & 0.098 \\
\hline Number of observations & 413,221 & 412,269 & 412,269 & 413,221 & 412,269 & 412,269 & 413,221 & 412,269 & 412,269 \\
\hline
\end{tabular}

Notes: Country and year fixed effects are used in all models. Standard errors, clustered at each DHS cluster for each survey round, are given in parentheses. BMI $=$ Body mass index $\left(\mathrm{kg} / \mathrm{m}^{2}\right)$. $\mathrm{p}<0.10$, ** $p<0.05,{ }^{* *} p<0.01$. 


\section{ABOUT THE AUTHORS}

Kibrom A. Abay is a Research Fellow in the Development Strategy and Governance Division (DSGD) of the International Food Policy Research Institute (IFPRI), based in Cairo. Hosam Ibrahim is a Senior Research Assistant with IFPRI's Egypt Strategy Support Program (ESSP), based in Cairo. Clemens Breisinger is a Senior Research Fellow in DSGD of IFPRI and Head of IFPRI's ESSP, based in Cairo.

\section{ACKNOWLEDGMENTS}

The authors acknowledge the financial support from the Food and Agriculture Organization of the United Nations. We received valuable comments from Harold Alderman, Kalle Hirvonen, and Todd Benson, all at IFPRI. The DHS data used in this paper were compiled by Advancing Research on Nutrition and Agriculture (ARENA) team at IFPRI. 